\title{
Silymarin, Natural Flavonolignans from Milk Thistle
}

\author{
Sameh AbouZid \\ Faculty of Pharmacy, University of Beni-Sueif, \\ Egypt
}

\section{Introduction}

Plants are a valuable source of pharmaceuticals, food ingredients, agrochemicals, insecticides, flavors and pigments. These compounds are called secondary metabolites. These are compounds with a restricted occurrence in taxonomic groups that are not essential for an organism to live but play a role in the interaction of the organism with its environment, ensuring the survival of the organism in its ecosystem (Verpoorte and Alfermann, 2000).

Milk thistle or St. Mary's thistle [Silybum marianum (L.) Gaertn. (Syn. Cardus marianum) Asteraceae] is an annual or biennial herb. The plant is native to the Mediterranean and North African regions (Boulos, 2000). It grows wild throughout Europe, North Africa, Americas and Australia (Hamid et al., 1983). The plant reaches to heights 10 feet. It has a stem of $20-150 \mathrm{~cm}$ high, erect, ridged and branched in the upper part. A distinguishing characteristic of milk thistle is the white patches found along the veins of the dark green leaves (Fig. 1). The broad leaves are deeply lobed, $50 \mathrm{~cm}$ long and $25 \mathrm{~cm}$ wide. The leaf margins are yellow and tipped with woody spines (3-12 $\mathrm{mm}$ long). The leaves are alternate and clasping to the stem. Each stem ends with solitary composite flower heads, about 2 inches in diameter, consisting of purple disc florets. The flower heads of milk thistle differ from other thistles by the presence of leathery bracts that are also tipped with stiff spines. The fruits (Fig. 2) are hard skimmed achenes, 6-8 $\mathrm{mm}$ long flat, smooth and shiny dark brown in color. The fruits yield 1.5-3\% of an isomeric mixture of flavonolignans collectively known as silymarin (Morazzoni and Bombardelli, 1995). Silymarin accumulates mainly in the external cover of the fruits of S. marianum (Madrid and Corchete, 2010).

\section{Chemistry of flavonolignans}

The principal components of silymarin are silybin A, silybin B, isosilybin A, isosilybin B, silychristin A, silychristin B and silydianin (Fig. 3). The first six compounds exist as equimolar mixtures as trans diastereoisomers. These diastereomers have very similar $1 \mathrm{H}$ and ${ }^{13} \mathrm{C}$ NMR spectra and have no characteristic signals for facile identification of the individual isomers (Lee and Liu, 2003). A number of other chemically related compounds have been found in the fruits including dehydrosilybin, desoxysilychristin, desoxysilydianin, silandrin, silybinome, silyhermin and neosilymermin. The common feature of these 


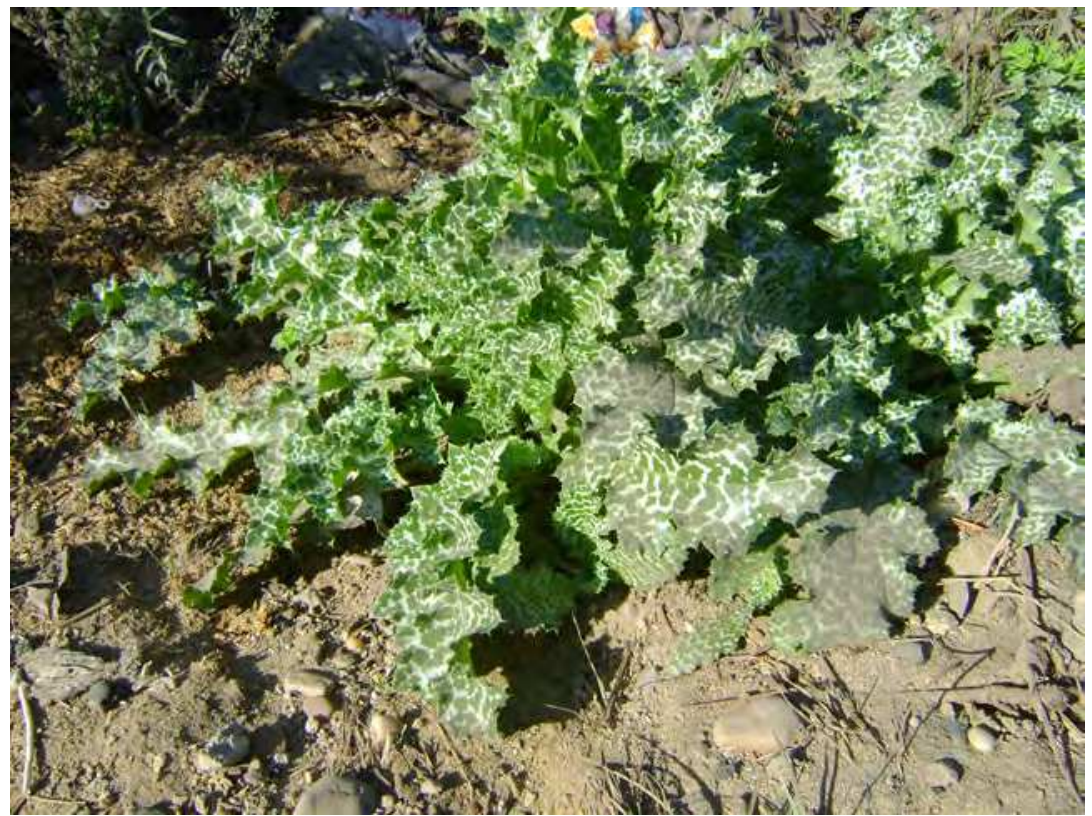

Fig. 1. Milk thistle with white patches along the veins of dark green leaves.

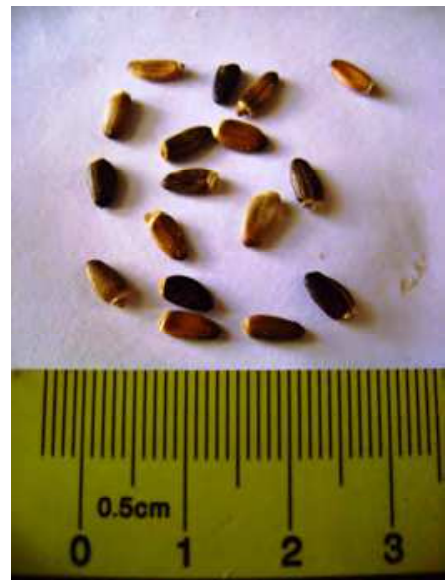

Fig. 2. Silybum marianum fruits.

compounds is a flavonolignan skeleton $\left(\mathrm{C}_{25} \mathrm{H}_{22} \mathrm{O}_{10}\right.$, mol wt 482$)$. Basically, flavonolignan nucleus consists of the dihydroflavanol taxifolin linked to coniferyl alcohol moiety through an oxeran ring. The oxeran ring is responsible for the biological activity of silymarin, and opening of this ring results in loss of activity. Only silybins and isosilybins contain the 1,4dioxane ring system in their structure. Silybin and isosilybin have the same trans conformation of C-2, C-3 and C-7', C-8'. Silybin is considered the major and most active component in silymarin (Ligeret et al., 2008; Kim et al., 2009). The chemical structure of 
silybin has been identified in 1975 using a degradative method (Lee and Liu, 2003). The first trials to synthesize silybin suffered from the problem of giving a product which is a mixture of regioisomers, silybin and isosilybin (57:43). Regioselective synthesis of diastereomeric silybin in $63 \%$ overall yield was achieved by synthesizing a key intermediate which was coupled with 2,4,6-trimethoxyacetophenone to form a chalcone intermediate. Epoxidation, deprotection and acidic cyclization were followed (Tanaka et al., 1985).<smiles>COc1cc([C@H]2Oc3ccc([C@@H]4Oc5cc(O)cc(O)c5C(=O)C4O)cc3O[C@H]2CO)ccc1O</smiles>

Silybin A<smiles>COc1ccc([C@H]2Oc3ccc([C@@H]4Oc5cc(O)cc(O)c5C(=O)C4O)cc3O[C@H]2CO)cc1O</smiles>

Isosilybin A<smiles>COc1cc([C@H]2Oc3c(O)cc([C@@H]4Oc5cc(O)cc(O)c5C(=O)[C@H]4O)cc3[C@@H]2CO)ccc1O</smiles>

Silychristin A<smiles>COc1cc([C@H]2Oc3cc([C@@H]4Oc5ccc(O)cc5C(O)C4C(=O)O)ccc3OC2CO)ccc1O</smiles>

Silybin B<smiles>COc1ccc([C@H]2Oc3ccc([C@@H]4Oc5cc(O)cc(O)c5C(O)C(O)[C@H]4O)cc3O[C@H]2C)cc1O</smiles>

Isosilybin B

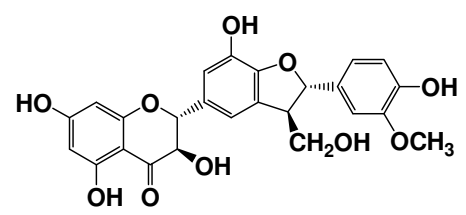

Silychristin B

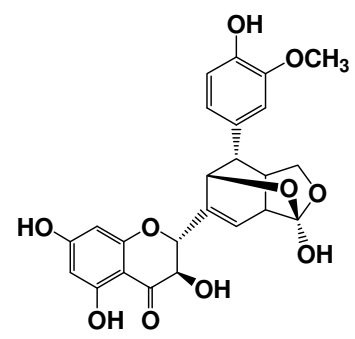

Silydianin

Fig. 3. Chemical structures of silymarin components. 


\section{Analysis of flavonolignans}

Extract obtained from the fruits of S. marianum is available worldwide in the pharmaceutical market as antihepatotoxic drug under a variety of brand names. There are many products that contain silymarin either as a single component or in a mixture with other active constituents. The extract contains about $80 \% \mathrm{wt} / \mathrm{wt}$ of flavonolignans. Due to its poor water solubility and thus low bioavailability, silymarin is complexed with phosphatidylcholin, $\beta$ cyclodextrin or even given as glycosides, which have better water solubility and higher activity. A method for extraction of silymarin from plants on an industrial level has been reported (Madaus et al. 1983). In this method large part of the fruit oil is removed by cold pressing, the compressed mass is broken up, the pressed residue is extracted with ethyl acetate and the ethyl acetate extract is evaporated and processed. There is a need to have a selective and accurate analytical method for qualitative and quantitative determination of silymarin flavonolignan components during standardization of the extract. This is expressed as silymarin percentage and it corresponds to the sum of silybins, isosilybins, and silychristins and silydianin concentrations. It is important that the analytical method characterizes and quantifies each component in silymarin.

\subsection{Thin layer chromatography analysis}

Flavonolignans were analyzed by Thin Layer Chromatography (TLC) (Wagner et al., 2009). Chloroform-acetone-formic acid (75:16.5:8.5) was used as a solvent system and detection was done using natural products-polyethylene glycol reagent. Silymarin is characterized in UV-365 nm by two intense green-blue fluorescent zones of silybin/isosilybin $\left(R_{\mathrm{f}}=0.6\right)$, silychristin $\left(R_{\mathrm{f}}=0.35\right)$ and an orange zone of taxifolin $\left(R_{\mathrm{f}}=0.4\right)$.

\subsection{UV-visible spectrophotometry analysis}

UV-visible spectrophotometry was proposed for the quantitative determination of flavonolignans (Famacopea Ufficiale Italiana, 1985). This spectrophotometric method is time consuming, shows a non-satisfactory repeatability and measures total and not individual flavonoligans. A fast, simple and sensitive spectrophotometric method for determination of silymarin in pure form and in pharmaceutical formulations was reported. This method was based on oxidation with potassium permanganate at $\mathrm{pH}$ 7. The reaction was followed spectrophotometrically by measuring the decrease in the absorbance at $530 \mathrm{~nm}$ (Rahman et al., 2004).

\subsection{High performance liquid chromatography analysis}

High Performance Liquid Chromatography (HPLC) was proposed as a method for determination of silymarin (Quaglia et al., 1999). Two reversed stationary phases, RP-18 and $\mathrm{RP}-8$, were compared for resolution of all considered flavonolignans. The RP-18 stationary phase showed good separation among silybin and isosilybin, while silydianin and silychristin were not baseline resolved. The increase in water concentration in the mobile phase allowed the separation of two distereomers of silybin. RP-8 stationary phase, a more polar phase, improved the resolution of peaks related to all flavonolignans but did not allow the resolution of the two silybin diastereomers. Among the advantages of this method are precision, sensitivity, ability to measure individual constituents in a mixture, the good 
separation of all compounds allowed the purity control of each peak, plotting of UV spectra, useful for the peak identification and a more correct quantification. However, time consumption, the need for pre-purification step and availability of pure reference compounds are the main disadvantages of HPLC. Analysis of silymarin components by HPLC on RP-18 in our laboratory only showed separation of the two diastereomers of silybin. However, the two peaks were not base-line resolved (Fig. 4).

\subsection{Capillary electrophoresis analysis}

Capillary zone electrophoresis has been proposed as a method for separation and determination of silymarin components (Kvasnička et al., 2003). Repeatability, accuracy, linearity and limit of detection were evaluated. The method was comparable to HPLC results. Shorter analysis time and better resolution of silydianin and silychristin from sample constituents were the main advantages of this method. High Performance Capillary Electrophoresis (HPCE) was used for determination of silymarin in the extract of S. marianum using borate buffer solution at $\mathrm{pH}$ 9. At this $\mathrm{pH}$ the flavonolignans having many phenolic groups in their structure were negatively charged (Quaglia et al., 1999). In these conditions isosilybin co-eluted together with silybin. Adding $12 \mathrm{mM}$ dimethyl $\beta$-cyclodextrins solution to the running buffer, the separation of silybin from isosilybin was obtained.

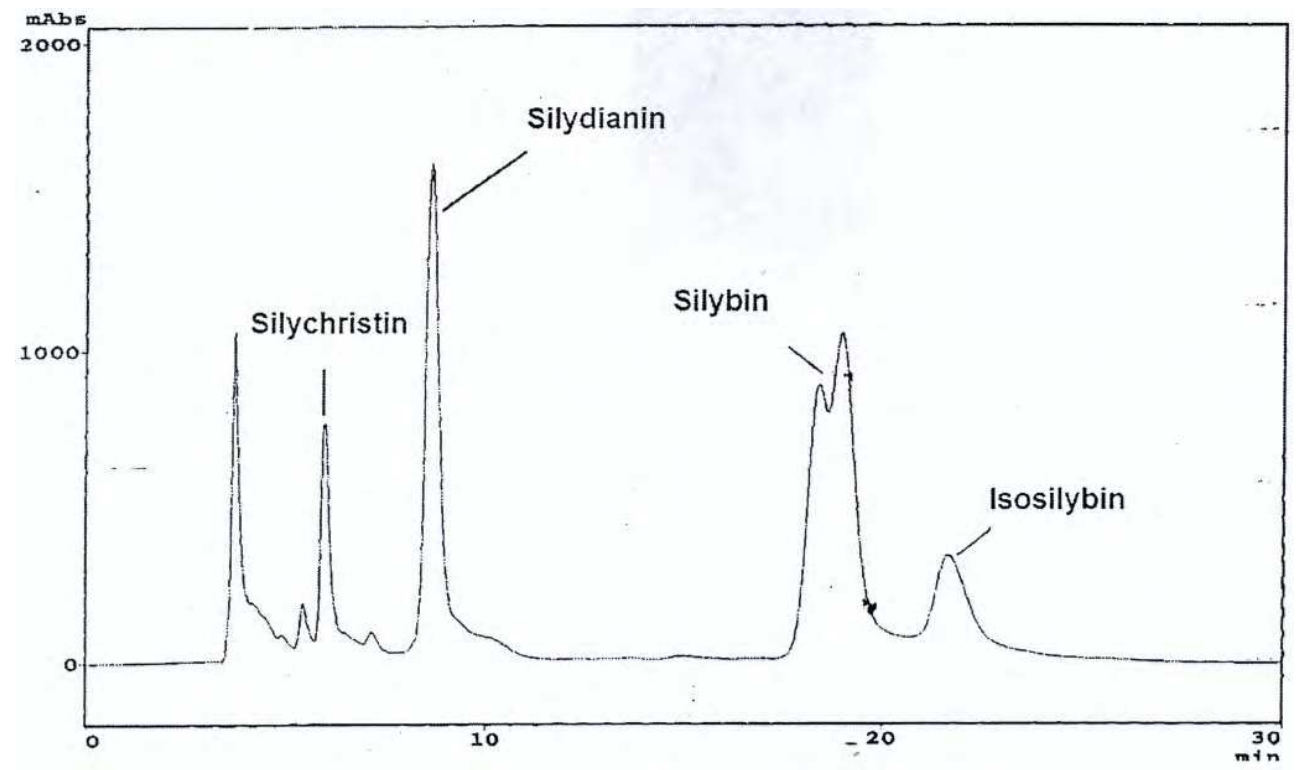

Fig. 5. Analysis of silymarin components by HPLC on RP18 (analysis was carried out in author laboratory).

\subsection{Ultra performance liquid chromatography analysis}

Ultra-Performance Liquid Chromatography (UPLC) offer many advantages over traditional HPLC for separation and quantification of multicomponent analytes such as silymarin 
components. Among these advantages are short analysis time, maintaining the resolution and increasing peak capacity and sensitivity. Complete separation of the seven major active flavonolignans of silymarin by UPLC RP18 column was reported (Wang et al., 2010). In this study, the use of electrospray ionization tandem mass spectrometry allowed to obtain detailed analysis of fragmentation and distinguish between the seven flavonolignans for online identification. Advantages and disadvantages of different methods for quantitative analysis of flavonolignan components in silymarin are summarized in table 1.

\begin{tabular}{|c|c|c|}
\hline Method & Advantages & Disadvantages \\
\hline Spectrophotometric & $\begin{array}{l}\text { - Fast and simple } \\
\text { - Sensitive }\end{array}$ & $\begin{array}{l}\text { - Individual flavonolignans are } \\
\text { not quantified }\end{array}$ \\
\hline HPLC & $\begin{array}{ll}\text { - } & \text { Precise and sensitive } \\
\text { - } & \text { Individual flavonolignans are } \\
\text { - } & \text { Puantified } \\
\text { - } & \text { Purity control }\end{array}$ & $\begin{array}{ll}\text { - } & \text { Not all flavonolignans are } \\
\text { - } & \text { Time consuming } \\
\text { - } & \text { Needs pre-purification step } \\
\text { - } & \text { Pure reference compounds are } \\
& \text { needed }\end{array}$ \\
\hline HPCE & $\begin{array}{ll}\text { - } & \text { Shorter analysis } \\
\text { - } & \text { Less solvent consumption } \\
& \text { Individual flavonolignans are } \\
& \text { quantified including } \\
& \text { diastereomers }\end{array}$ & - $\quad$ Needs pre-purification step \\
\hline UPLC & $\begin{array}{ll}\text { - } & \text { Short analysis time } \\
\text { - } & \text { Less solvent consumption } \\
\text { - } & \text { Increased resolution } \\
& \text { sensitivity }\end{array}$ & $\begin{array}{ll}\text { - } & \text { Expensive } \\
\text { - } & \text { Needs pre-purification step } \\
\text { - } & \text { Needs calibration curve }\end{array}$ \\
\hline
\end{tabular}

Table 1. Advantages and disadvantages of different methods for quantitative analysis of flavonolignan components in silymarin.

\section{Biosynthesis of flavonolignans in Silybum marianum}

Flavonolignans are formed by combination of flavonoid and lignan structures. This occurs by oxidative coupling processes between a flavonoid and a phenylpropanoid, usually coniferyl alcohol (Dewich, 2002). Oxidative coupling occurs between free radical generated from the flavanol taxifolin and the free radical generated from coniferyl alcohol. This would lead to an adduct formation. This adduct could cyclize by attachment of the phenol nucleophile on to the quinine methide generated from coniferyl alcohol (Figure 5). The product in this case would be silybin. The fact that silybin exists in $S$. marianum in a mixture of two diastereomers reveals that the radical coupling reaction is not stereospecific. This is also true for isosilybin and silychristin. The latter flavonolignan originate from a mesomer of the taxifolin-derived free radical. Silydianin has a more complex structure and is formed by intramolecular cyclization of the coupling product. This is followed by hemiketal formation. 
<smiles>O=C1c2c(O)cc(O)cc2O[C@H](c2ccc(O)c(O)c2)[C@@H]1O</smiles>

Taxifolin (flavonoid)<smiles>CC(C)(C)CC(C)(C)C</smiles><smiles>COc1ccc(/C=C/CO)cc1O</smiles>

Coniferyl alcohol (phenylpropanoid)

$$
\downarrow-\mathrm{e}
$$<smiles>COC1CC(=CCCO)CCC1=O</smiles>
Radical coupling<smiles>COC1=CC(=CC(O)Oc2ccc([C@H]3Oc4cc(O)cc(O)c4C(=O)[C@H]3O)cc2O)C=CC1=O</smiles><smiles></smiles><smiles>COC1=CC=C2C=C(O[C@@H]1c1ccc(O)c(OC)c1)C(CO)O[C@H]1[C@H]2Oc2cc(O)cc(O)c2C(=O)[C@@H]1O</smiles><smiles>COc1cc([C@H]2Oc3cc([C@H]4Oc5cc(O)cc(O)c5C(=O)[C@H]4O)ccc3O[C@@H]2CO)ccc1O</smiles>

Fig. 5. Proposed biosynthetic pathway to silybin in Silybum marianum.

\section{Biological activity of flavonolignans}

Silymarin has been used for centuries to treat liver, spleen and gall bladder disorders (Shaker et al., 2010). It is known to possess hepatoprotective, antioxidant (Morazzoni and Bombardelli, 1995), anticancer (Zi et al., 1997), anti-inflammatory (De La Puerta, 1996) and anti-diabetic (Maghrani et al., 2004) properties. As a hepatoprotective agent, silymarin is used for oral treatment of toxic liver damage and for the therapy of chronic inflammatory liver diseases (Flora et al., 1998). 


\subsection{Hepatoprotective activity}

Silymarin is one of the most investigated plant extracts with known mechanisms of action for oral treatment of toxic liver damage (Hiroshi et al., 1984). Silymarin is used as a protective treatment in acute and chronic liver diseases (Flora et al., 1998). Silymarin supports the liver cells through multifactor action including binding to cell membrane to suppress toxin penetration into the hepatic cells, increasing superoxide dismutase activity (Feher and Vereckei, 1991), increasing glutathione tissue level (Pietrangelo et al., 1995), inhibition of lipid peroxidation (Bosisio et al., 1992; Carini et al., 1992) and enhancing hepatocyte protein synthesis (Takahara et al., 1986). The hepatoprotective activity of silymarin can be explained based on antioxidant properties due to the phenolic nature of flavonolignans. It also acts through stimulating liver cells regeneration and cell membrane stabilization to prevent hepatotoxic agents from entering hepatocytes (Fraschini et al., 2002). Recently it has been shown that flavonolignans inhibit leucotriene production; this inhibition explains their anti-inflammatory and antifibrotic activity (Dehmlow et al., 1996).

\subsection{Anticancer activity of silymarin}

Silymarin is also beneficial for reducing the chances for developing certain cancers (Deep et al., 2007; Zhao et al., 1999). The molecular targets of silymarin for cancer prevention have been studied (Ramasamy and Agrawal, 2008). Silymarin interfere with the expressions of cell cycle regulators and proteins involved in apoptosis to modulate the imbalance between cell survival and apoptosis. Sy-Cordero et al., 2010, isolated four key flavonolignan diastereoisomers (silybin A, silybin B, isosilybin A and isosilybin B) from S. marianum in gram scale. These compounds and other two related analogues, present in extremely minute quantities, were evaluated for antiproliferative/cytotoxic activity against human prostate cancer cell lines. Isosilybin B showed the most potent activity (Deep et al., 2007; Deep et al., 2008a; Deep et al., 2008b). The isolation of six isomers afforded a preliminary analysis of structure-activity relationship toward prostate cancer prevention. The results suggested that an ortho relationship for the hydroxyl and methoxy substituents in silybin A, silybin B, isosilybin A and isosilybin B was more favorable than the meta relationship for the same substituents in the minor flavonolignans. Silymarin suppressed UVA-induced oxidative stress that can induce skin damage (Svobodová et al., 2007). Therefore, topical application of silymarin can be a useful strategy for protecting against skin cancer.

\subsection{Anti-inflammatory activity}

Silymarin seems to possess anti-inflammatory properties by acting through different mechanisms such as its antioxidant action, membrane-stabilizing effect and inhibition of the production or release of inflammatory mediators such as arachidonic acid metabolites (Breschi et al., 2002). Gastric anti-ulcer activity of silymarin has been reported (Alarcon et al., 1992). This action was attributed to the inhibition of enzymatic peroxidation in the lipoxygenase pathway and free radical scavenging activity (Bauman et al., 1980). Silymarin exhibited significant anti-inflammatory and antiarthritic activities in the papaya latex induced model of inflammation and mycobacterial adjuvant induced arthritis in rats (Gupta et al., 2000). This action is mediated through inhibition of 5-lipoxygenase. 


\subsection{Effect on asthma}

Activity of silymarin was examined against bronchial anaphylaxis and against postanaphylactic, propranolol- or platelet activating factor-induced hyperreactivity in guineapigs (Breschi et al., 2002). Silymarin pretreatment reduced the bronchospasm induced by antigen-challenge in sensitized animals. This protective effect was due to indirect mechanism that reduces airway responsiveness to histamine, and consequently the immediate anaphylactic response. Therefore, silymarin can be used as protective agent in the management of asthmatic disorders.

\subsection{Immunostimulatory activity}

Several studies have reported the immunostimulatory actions of silymarin (Wilarusmee et al., 2002). The effect of treatment with silymarin was studied on glutathione level and proliferation of peripheral blood mononuclear cells of $\beta$-thalassemia major patients (Alidoost et al., 2006). In vitro treatment with $10 \mathrm{~g} / \mathrm{ml}$ silymarin restored glutathione levels and enhanced cellular proliferation. This was explained by its antioxidant activity.

\subsection{Treatment of obsessive-compulsive disorder}

Many patients cannot tolerate the side effects of pharmaceutical agents available for treatment of obsessive-compulsive disorder, do not respond properly to the treatment or the medications lose their effectiveness after a period of treatment. An 8-week pilot doubleblind randomized clinical trial on 35 adult patients was conducted to compare the efficacy of the extract of $S$. marianum with fluoxetine in the treatment of obsessive-compulsive disorder (Sayyah et al., 2010). The results showed that the extract of S. marianum has positive effects on obsession and compulsion starting from the fifth week. There were no any serious side effects accompanying $S$. marianum extract administration.

\subsection{Hyperprolactinemic effect}

S. marianum fruits have been traditionally used by nursing mothers for stimulating milk production (Newall et al., 1996). It was demonstrated that milk thistle increases lactation (Carotenuto and Di Pierro, 2005). The mechanism that led to the increase in lactation has been studied by measuring the concentration of circulating prolactin in female rats treated with silymarin (Capasso et al., 2009). It was shown that silymarin is able to produce a significant increase in circulating prolactin levels after oral administration. The levels of prolactin remains elevated for up to 66 days after silymarin discontinuation. Fig. 6 shows a summary of the wide range of biological activities attributed to silymain.

\subsection{Toxicity of silymarin}

An average daily dose of silymarin ( $420 \mathrm{mg}$ /day for 41 months) was found to be non-toxic, relative to placebo, in clinical trials (Tamayo and Diamond, 2007). Drug-drug interaction and liver toxicity by interference with co-drugs by induction or inhibition of cytochromeP450 is a major concern for the use of silymarin (Izzo and Ernst, 2009). Studies were performed to investigate the potential for hepatotoxicity, cytochrome-P450 isoenzymes induction and inhibition on dry extract from S. marianum, as contained in HEPAR-PASC ${ }^{\circledR}$ film-coated tablets (Doehmer et al., 2011). The results indicated that interference or 
hepatotoxicity of the dry extract from $S$. marianum at the recommended maximum daily dose equivalent to $210 \mathrm{mg}$ silybin is unlikely and is to be considered safe.

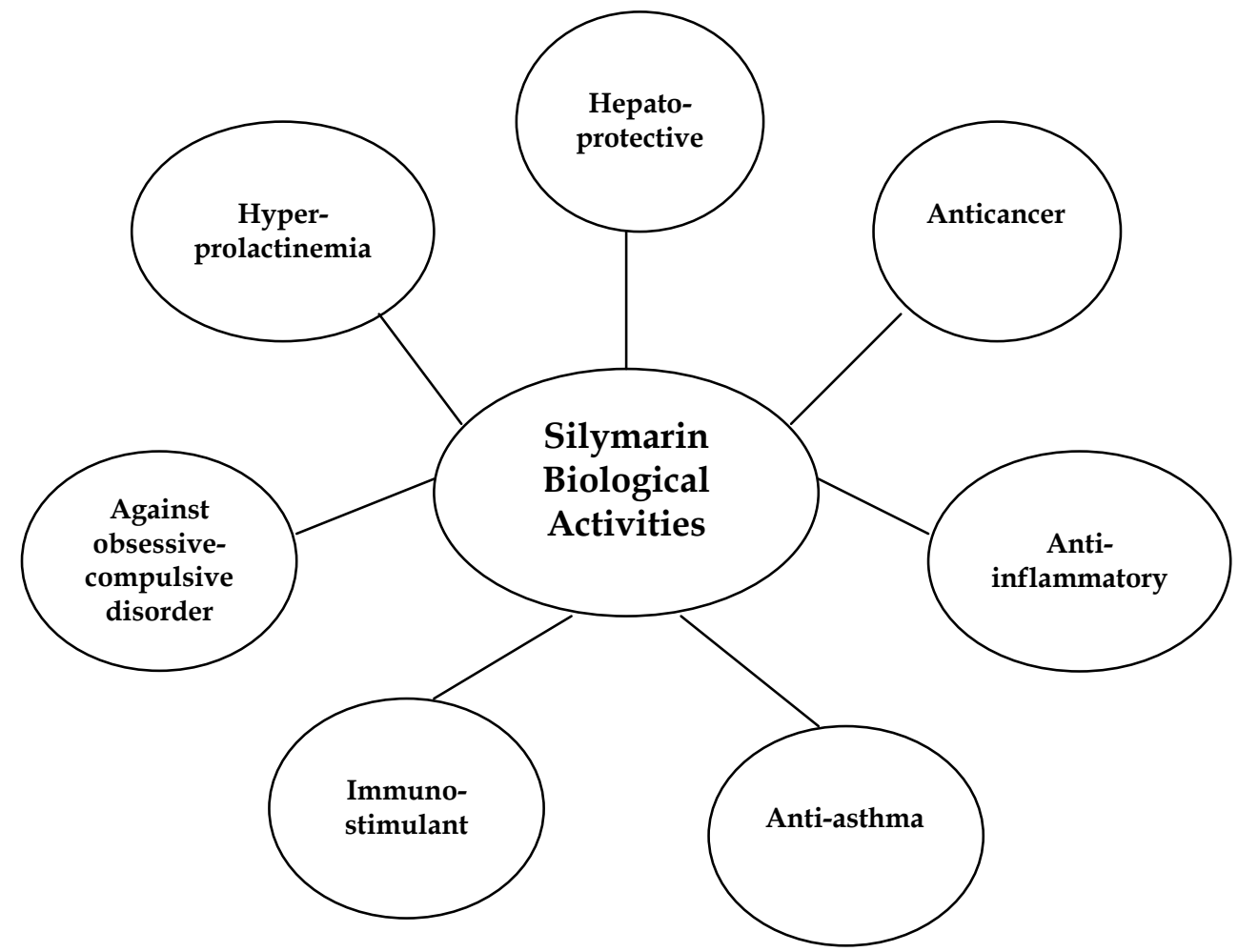

Fig. 6. Biological activities of silymarin.

\section{Tissue culture studies}

Plant tissue culture can be a potential source for important secondary metabolites (Misawa, 1994). This is based mainly on using plant cultures in a similar manner to microbial fermentation for factory-type production of pharmaceuticals and food additives. This technology has some advantages over conventional agricultural methods: production is independent of variation in crop quality or failure, yield of secondary metabolites would be constant and geared to demand, there is no difficulty in applying good manufacturing practice to the early stages of production, production would be possible anywhere under strictly controlled conditions, independent of political problems, free from risk of contamination with pesticides, herbicides or fertilizers and new methods of production can be patented (AbouZid et al., 2008). Cell suspension culture and hairy root culture were established from S. marianum. The former is established from callus tissue that developed on injured plant surface as a result of wounding or exogenous hormones (Fig. 7). The latter represent an approach to increase the yield of flavonolignans using morphologically differentiated/organized cultures. 


\subsection{Cell culture}

In vitro cultured cells of $S$. marianum may offer an alternative and renewable source for this valuable natural product. However, the yield of silymarin was very low or sometimes not detectable in undifferentiated cultured cells (Becker and Schrall, 1977). In order to obtain silymarin in concentrations high enough for commercial manufacturing, many approaches have been made to stimulate the productivity of silymarin in cultured cells of S. marianum. These approaches compromise changes in the media composition (Cacho et al., 1999), treatment with elicitors such as yeast extract and methyl jasmonate (Sánchez-Sampedro et al., 2005a), addition of precursor (Tůmová et al., 2006) and morphological differentiation. Such approaches for improving silymarin production by manipulating plant cell cultures may also help in studying signal transduction pathways, cloning biosynthetic genes, studying metabolic flux and regulation of silymarin production (Zhao et al., 2005).

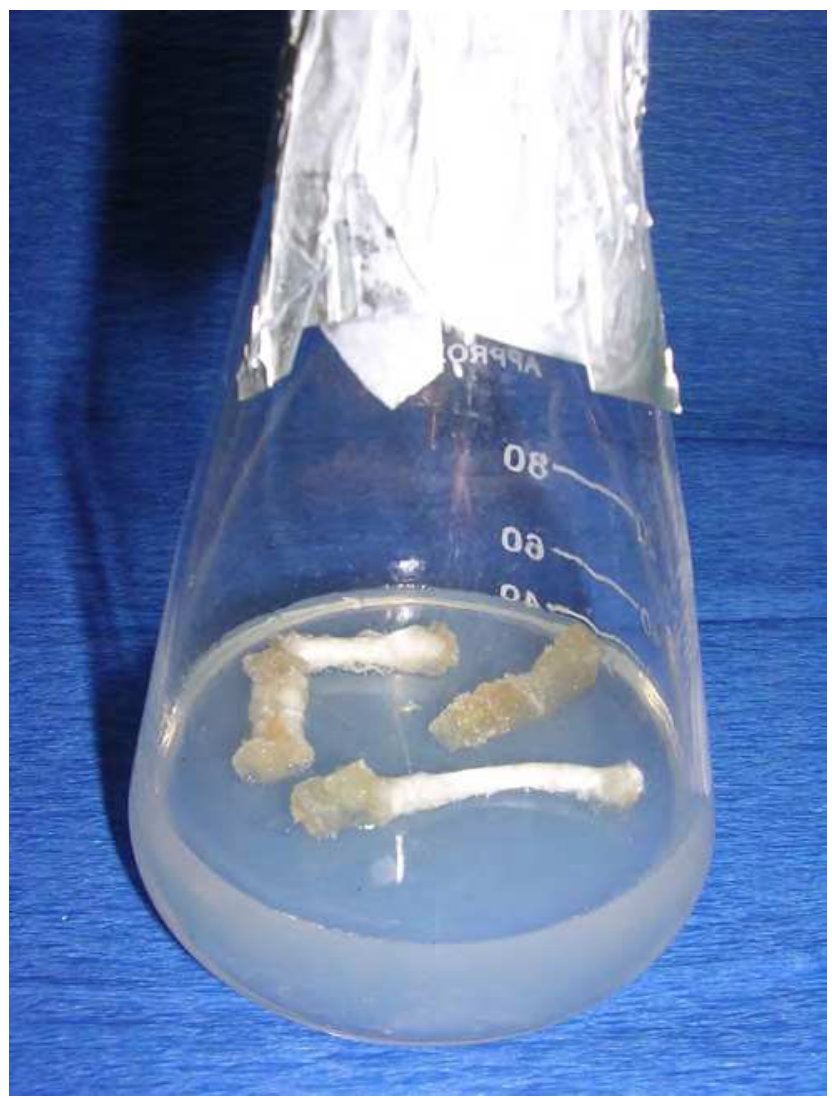

Fig. 7. Callus of Silybum marianum developed on explants.

Becker and Schrall, (1977) cultured cotyledon explants on MS media using different growth hormones for establishment of cell suspension culture. Typical flavonolignans of $S$. marianum were not detected. This was possible after feeding coniferyl alcohol and taxifolin 
to cell suspension cultures (Schrall and Becker 1977). Feeding the culture medium with precursor of coniferyl alcohol offered enhancement of silydianin production but other components of silymarin were not influenced (Tůmová et al., 2006). Cacho et al. (1999) reported that callus and cell cultures of $S$. marianum could produce silymarin but to a lesser extent than that accumulates in the fruits. They also reported that elimination of calcium ion positively affected silymarin production. This point was further confirmed by SánchezSampedro et al. (2005a), who also reported that silymarin accumulation was not altered by treatment of cultures with the calcium ionophore A23187. These results suggest that inhibition of external and internal calcium fluxes play a significant role in flavonolignans metabolism in S. marianum cell cultures. Sánchez-Sampedro et al. (2005b) reported that yeast extract and methyl jasmonate elicited the production of silymarin. Elicitation is one of the most effective approaches to enhance the yield of secondary metabolites in in vitro cultures (Namdeo, 2007). It has been shown that elicitors can affect level of secondary metabolites in medicinal plants by modulating the rates of biosynthesis, accumulation, and/or vacuolar transit, turnover and degradation (Barz et al., 1990). Jasmonic acid and its methyl ester are known to be involved in the plant defense response through altering the gene expression. The mechanism by which jasmonate induces gene expression was studied in Catharanthus roseus (van der Fits and Memelink, 2000). In this plant species induction occurs through an ORCA3 transcription factor with a conserved jasmonate-response domain. The use of methyl jasmonate as an elicitor has an advantage of being only one compound of welldefined chemical structure. The effect of elicitation with picloram, jasmonic acid and light on silymarin production was reported (Hasanloo et al., 2008). The greatest silymarin content $(0.41 \mathrm{mg} / \mathrm{g} \mathrm{DW})$ was obtained with $3 \mathrm{mg} / 1$ picloram and $2 \mathrm{mg} / 1$ jasmonic acid in the dark after 28 days. The sequence of the signaling processes leading to stimulation of flavonolignan production by methyl jasmonate is not well-known. Madrid and Corchete, 2010, studied the possible involvement of a phospholipase D-mediated lipid signaling in the elicitation of flavonolignans. It was reported that methyl jasmonate increased the activity of phospholipase D. Mastoparan, a phospholipase D activity stimulator, caused a substantial increase in silymarin production. Phosphatidic acid, a product of phospholipase D activity, promoted silymarin accumulation. N-butanol which inhibits phospholipase D activity prevented silymarin elicitation by methyl jasmonate or mastoparan.

\subsection{Root culture}

Production of flavonolignans from root cultures (Fig. 8) of S. marianum was reported before (Alikaridis et al ., 2000). Silybin $\left(1.79 \times 10^{-3} \% \mathrm{DW}\right)$ and silychristin $\left(0.81 \times 10^{-3} \% \mathrm{DW}\right)$ were the major flavonolignans produced by the established root cultures. In the referred study hairy root cultures of $S$. marianum were established. Hairy root cultures are the roots obtained by genetic transformation of plant tissues with the pathogenic soil bacterium Agrobacterium rhizogenes. These roots can then be cultured on hormone-free media and have three main advantages: genetic and biochemical stability, cultivation without addition of growth regulators and ability to give high final biomasses from low inocula.

Salicylic acid was effective in increasing the flavonolignan content 2.42 times in hairy root cultures of S. marianum higher than control cultures (Khalili et al., 2009). Yeast extract stimulated flavonolignan production in hairy root cultures two-fold higher than the control cultures. Moreover, it was reported that yeast extract treatment induced the activity of 


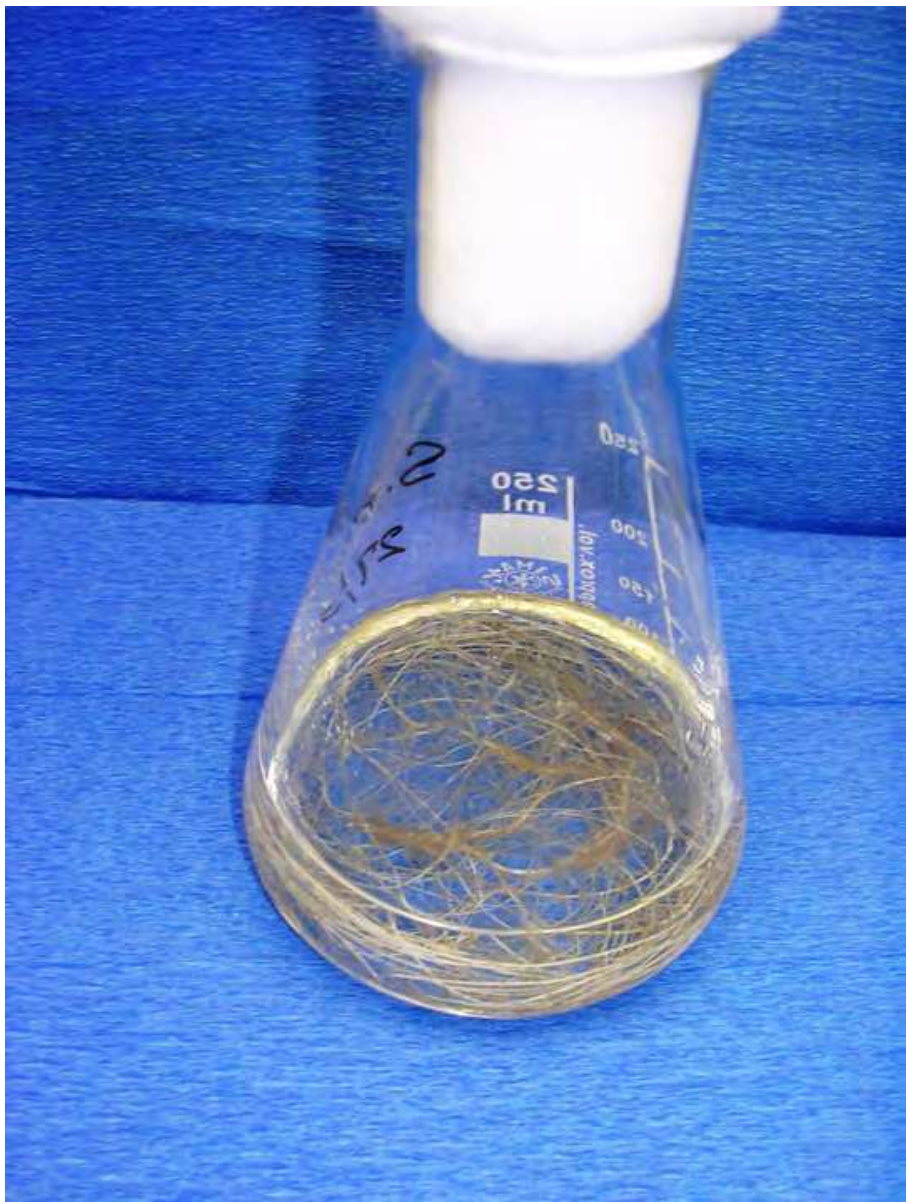

Fig. 8. Root culture of Silybum marianum growing in Murashige and Skoog medium.

lipoxygenase to allow for the production of jasmonate. It was concluded that jasmonate signaling is an integral part of the yeast extract signal transduction for the production of flavonolignans (Hasanloo et al., 2009).

\section{Future directions}

Plant tissue culture studies have contributed to our understanding of biosynthesis and regulation of silymarin in S. marianum. Using elicitation technology may offer an effective approach to improve silymarin production for industrial purpose. However, the possible signaling pathway that may be involved in accumulation of silymarin is still unknown. Understanding the basic components of this pathway is mandatory before these biotechnological methods can replace field crops as the basic source of pharmaceutical raw material. Establishment of plant tissue culture systems able to produce these biologically valuable compounds in high yield will facilitate such studies. 


\section{Conclusion}

Milk thistle is an annual or biennial herb native to the Mediterranean and North African regions. The fruits of the plant contain an isomeric mixture of flavonolignans collectively known as silymarin. Basically, flavonolignan nucleus consists of the dihydroflavanol taxifolin linked to coniferyl alcohol moiety through an oxeran ring. Little is known about the coupling of coniferyl alcohol to taxifolin. Silymarin is widely used as a hepatoprotective agent for oral treatment of toxic liver damage and for the therapy of chronic inflammatory liver diseases. The hepatoprotective activity of silymarin is based on antioxidant properties, stimulating liver cells regeneration and cell membrane stabilization to prevent hepatotoxic agents from entering hepatocytes. It has been shown that flavonolignans exhibit wide range of biological activity including anticancer, anti-inflammatory, hyperprolactinemic properties. Various methods have been developed for analysis of the content and composition of main silymarin components in plant material and pharmaceuticals. Among these methods are thin layer chromatography, spectrophotometric, high performance liquid chromatography, capillary zone electrophoresis and ultra performance liquid chromatography. In vitro cultured cells of S. marianum may offer an alternative and renewable source for this valuable natural product. Flavonolignans production in cell and root cultures of S. marianum has been reported. Many approaches have been used to increase the yield of flavonolignans in S. marianum tissue culture including change in media composition, addition of precursors and elicitation.

\section{References}

AbouZid, S., Nasib, A., Khan, S., Qureshi, J., Choudhary, M.I. (2010) Withaferin A production by root cultures of Withania coagulans. International Journal of Applied Research in Natural Products 2(5), 23-27.

Alarcon, C., Martin, M.J., Marhuenda, E. (1992) Gastric anti-ulcer activity of silymarin, a lipoxygenase inhibitor, in rats. Journal of Pharmacy and Pharmacology 44, 929-931.

Alidoost, F., Gharagozloo, M., Bagherpour, B., Jafarian, A., Sajjadi, S.E., Hourfar, H., Moayedi, B. (2006) Effects of silymarin on the proliferation and glutathione levels of peripheral blood mononuclear cells from $\beta$-thalassemia major patients. International Journal of Immunopharmacology 6, 1305-1310.

Alikaridis, F., Papadakis, D., Pantelia, K., Kephalas, T. (2000) Flavonolignan production from Silybum marianum transformed and untransformed root cultures. Fitoterapia, 71(4), 379-384.

Barz, W.A., Beimen, B., Drae, U., Jaques, C., Sue, O.E., Upmeier, B. (1990) Turnover and storage of secondary products in cell cultures. In: Charlwood BV, Rhodes MJC, eds. Secondary products from plant tissue culture. Oxford: Clarendon Press, 79-102.

Baumann, J., Wurm, G., Von Bruhhansen, F. (1980) Prostaglandin relation to their oxygenscavenging properties. Achieves of Pharmacology 313, 330-337.

Becker, H., Schrall, R. (1977) Tissue and suspension cultures of Silybum marianum: the formation of flavanolignans by flavanoids and coniferyl alcohol. Planta Medica, 32(1), 27-32.

Bosisio, E., Benelli, C., Pirola, O. (1992) Effect of the flavolignans of Silybum marianum L. on lipid peroxidation in rat liver microsomes and freshly isolated hepatocytes. Pharmacology Research 25, 147-154.

Boulos, L. (2000) Flora of Egypt, (1 st $^{\text {st }}$ dition), Al Hadara Publishing Inc., Cairo, Egypt. 
Breschi, M.C., Martinotti, E., Apostoliti, F., Nieri, P. (2002) Protective effect of silymarin in antigen challenge- and histamin-induced brochoconstriction in in vivo guinea-pigs. European Journal of Pharmacology 437, 91-95.

Cacho, M., Moran, M., Corchete, P., Fernandez-Tarrago, J. (1999) Influence of medium composition on the accumulation of flavonolignans in cultured cells of Silybum marianum (L.) Gaertn. Plant Science 144, 63-68.

Capasso, R., Aviello, G., Capasso, F., Savino, F., Isso, A.A., Lembo, F., Borrelli, F. (2009) Silymarin $\mathrm{BIO}-\mathrm{C}^{\circledR}$, and extract from Silybum marianum fuits, induces hperprolactinemia in intact female rats. Phytomedicine 16, 839-844.

Carini, R., Comoglio, A., Albano, E., Poli, G. (1992) Lipid peroxidation and irreversible damage in the rat hepatocyte model: Protection by the silybin-phospholipid complex IdB 1016. Biochemical Pharmacology 43, 10, 2111-2115.

Carotenuto, D., Di Pierro, F. (2005) Studio sulla tollerabilità ed efficacia dela silimarina BIO$C^{\circledR}$ (Più̀latte ${ }^{\circledR}$ ) micronizzata come galattagogo. Acta Neonatology Pediatrics 4, 393-400.

De La Puerta, R. (1996) Effect of silymarin on different acute inflammation models and in leukocyte migration. Journal of Pharmacy and Pharmacology 48, 9, 968-970.

Deep, G., Oberlies, N.H., Kroll, D.J., Agarwal, R. (2007) Isosilybin B and isosilybin A inhibit growth, induce G1 arrest and cause apoptosis in human prostate cancer LNCaP and 22Rv1 cells. Carcinogenesis 28, 1533-1542.

Deep, G., Oberlies, N.H., Kroll, D.J., Agarwal, R. (2008) Isosilybin B causes androgen receptor degradation in human prostate carcinoma cells via P13K-Akt-Mdm2mediated pathway. Oncogene 27, 3986-3998.

Deep, G., Oberlies, N.H., Kroll, D.J., Agarwal, R. (2008) Identifying the differential effects of silymarin constituents on cell growth and cell cycle regulatory molecules in human prostate cancer cells. International Journal of Cancer 123, 41-50.

Dehmlow, C., Erhard, J., De Groot, H. (1996) Inhibition of Kupffer cell functions as an explanation for the hepatoprotective properties of silybinin. Hepatology 23, 749-754.

Dewick, P.M. (2002) Medicinal natural products. A Biosynthetic Approach, John Wiley \& Sons, Ltd, Chichester, UK.

Doehmer, J., Weiss, G., McGregor, G.P., Appel, K. (2011) Assessment of a dry extract from milk thistle (Silybum marianum) for interference with human liver cytochrome-P450 activities. Toxicology in Vitro 25, 1, 21-27.

Famacopea Ufficiale Italiana, ed. IX, vol. II 1673, Istituto Poligraficao e Zecca cello StatoRoma, 1985.

Flora, K., Hahn, M., Rosen, H., Benner, K. (1998) Milk thistle (Silybum marianum) for the therapy of liver disease. American Journal of Gastroenterology 93, 139-143.

Fraschini, F., Demartini, G., Esposti, D. (2002) Pharmacology of silymarin. Clinical Drug Investigation 22(1), 51-65.

Gupta, O.P., Sing, S., Bani, S., Sharma, N., Malhotra, S., Gupta, B.D., Banerjee, S.K., Handa, S.S. (2000) Antiinflammatory and antiarithritic activities of silymarin acting through inhibition of 5-lipoxygenase. Phytomedicine 7, 21-24.

Hamid, S., Sabir, A., Khan, S., Aziz, P. (1983) Experimental cultivation of Silybum marianum and chemical composition of its oil. Pakistan Journal of Scientific and Industrial Research 26, 244-246. 
Hasanloo, T., Kavari-Nejad, R.A., Majidi, E., Shams, Ardakani, M.R. (2008) Flavonolignan Production in Cell Suspension Culture of Silybum marianum. Pharmaceutical Biology 46(12), 876-882.

Hiroshi, H., Yoshinobu, K., Wagner, H., Manfred, F. (1984) antihepatotoxic actions of flavonolignans from Silybum marianum fruits. Planta Medica 51, 248-250.

Kim, S., Choi, J.H., Lim H.I., Lee, S., Kim, W.W., Kim J.S., Kim J., Choe, J., Yang, J., Nam, S.J., Lee, J.E. (2009) Silibinin prevents TPA-induced MMP-9 expression and VEGF secrestion by inactivation of the Raf/MEK/ERK pathway in MCF-7 human breast cancer cells. Phytomedicine 16, 573-580.

Klassen, C.D., Plaa, G.L. (1969) Comparison of the biochemical alteration elicited in liver of rats treated with carbon tetra chloride and chloroform. Biochemical Pharmacology 18(8), 2019- 2027.

Kvasnička, F., Biĩba, B., Ševčík, Voldřich, M., Krátká, J. (2003) Analysis of the active components of silymarin. Journal of Chromatography A 990, 239-245.

Izzo, A.A., Ernst, E. (2009) Interactions between herbal medicines and prescribed drugs: and updated systematic review. Drugs 69, 1777-1798.

Lee, D.Y.-W., Liu, Y. (2003) Molecular structure and stereochemistry of silybin A, silybin B, isosilybin A, and isosilybin B, isolated from Silybum marianum (Milk thistle). Journal of Natural Products 66, 1171-1174.

Lee, S.K., Mbwambo, Z.H.Y., Chung, H., Luyengi, L., Gamez, E.J.C., Mehta, R.G., Kinghorn, A.D., Pezzuto, J.M. (1998) Evaluation of the antioxidant potential of natural products. Combinatorial Chemistry and High Throughput Screening 1, 35-46.

Ligeret, H., Brault, A., Vallerand, D., Haddad, Y., Haddad, P.S. (2008) Antioxidant and mitochondrial protective effects of silibinin in cold preservation-warm reperfusion liver injury. Journal of Ethnopharmacology 115, 507-514.

Madrid, E., Corchete, P. (2010) Silymarin secretion and its elicitation by methyl jasmonate in cell cultures of Silybum marianum is mediated by phospholipase D-phosphatidic acid. Journal of Experimental Botany 61(3), 747-754.

Maghrani, M., Zeggwagh, N.A., Lemhadri, A., EI Amraoui, M., Michael, J.B., Eddouks, M. (2004) Study of the hypoglycaemic activity of Fraxinus excelsior and Silybum marianum in an animal model of type 1 diabetes mellitus. Journal of Ethnopharmacology 91, 309-316.

Madaus, R., Gorler, K., Molls, W. (1983) US patent 4,368,195.

Misawa, M. (1994) Plant tissue culture: an alternative for production of useful metabolites. FAO Agricultural Services Bulletin 108.

Morazzoni, P., Bombardelli, E. (1995) Silybum marianum (Cardus marianum). Fitoterapia 66, 342.

Murashige, T., Skoog, F. (1962) A revised medium for rapid growth and bioassays with tobacco tissue culture. Physiologia Plantarum 15, 473-497.

Namdeo, A.G. (2007) Plant cell elicitation for production of secondary metabolites: A review. Pharmacognosy Review 1, 69-79.

Newall, C.A., Anderson, L.A., Phillipson, J.D. (1996) Herbal Medicines: A Guide for HealthCare Professionals. Pharmaceutical Press, London pp. 46-47.

Quaglia, M.G., Bossù, E., Donati, E., Mazzanti, G., Brandt, A. (1999) Determination of silymarin in the extract from the dried silybum marianum fruits by high performance 
liquid chromatography and capillary electrophoresis. Journal of Pharmaceutical and Biomedical Analysis 19, 435-442.

Rahman, N., Khan, N.A., Azmi, S.N.H. (2004) Kinetic spectrophotometric method for the determination of silymarin in pharmaceutical formulations using potassium permanganate as antioxidant. Pharmazie 59, 112- 116.

Ramasamy, K., Agrawal, R. (2008) Multitargeted therapy of cancer by silymarin. Cancer Letters 269, 352-362.

Pietrangelo, A., Borella, F., Casalgrandi, G. (1995) Antioxidant activity of silybin in vivo during long-term iron overload in rats. Gastroenterology 109, 1941-1949.

Sánchez-Sampedro, M.A., Fernández-Tárrago, J., Corchete, P. (2005a) Yeast extract and methyl jasmonate-induced silymarin production in cell cultures of Silybum marianum (L.) Gaertn. Journal of Plant Physiology 162(10), 1177-1182.

Sánchez-Sampedro, M.A., Fernández-Tárrago, J., Corchete, P. (2005b) Some common signal transduction events are not necessary for the elicitor-induced accumulation of silymarin in cell cultures of Silybum marianum. Journal of Plant Physiology 165(14), 1466-1473.

Sayyah, M., Boostani, H., Pakseresht, S., Malayeri, A. (2010) Comparison of Silybum marianum (L.) Gaertn. with fluoxetine in the treatment of Obsessive-Compulsive Disorder. Progress in Neuro-Psychopharmacology \& Biological Psychiatry 34, 362-365.

Schrall, R., Becker, H. (1977) Produktion von catechinen und oligomeren proanthocyanidinen in callus- und suspensionskulturen von Cratжgus monogyna, Cratжgus oxyacantha und Ginkgo biloba. Planta Medica 32, 297-307.

Shah, J., Klessig, D.F. (1999) Salicylic acid: signal perception and transduction. In Libbenga, K., Hall. M., Hooykaas, P.J.J., editors. Biochemistry and Molecular Biology of Plant Hormones. Elsevier, Oxford, 513-541.

Shaker, E., Mahmoud, H., Mnaa, S. (2010) Silymarin, the antioxidant component and Silybum marianum extracts prevents liver damage. Food and Chemical Toxicology 48, 803-806.

Skehan, P., Storeng, R. (1990) New colorimetric cytotoxicity assay for anti cancer drug screening. Journal of National Cancer Institute 82, 1107-1112.

Svobodová, A., Zdařilová, A., Walterová, D., Vostálová, J. (2007) Flavonolignans from Silybum marianum moderate UVA-induced oxidative damage to HaCaT keratinocytes. Journal of Dermatological Science 48, 213-224.

Takahara, E., Ohta, S., Hirobe, M. (1986) Stimulatory effects of silibinin on the DNA synthesis in partially hepatectomized rate livers. Biochemical Pharmacology 35, 538541.

Tamayo, C., Diamond, S. (2007) Review of clinical trials evaluating safety and efficacy of milk thistle (Silybum marianum [L.] Gaertn.). Integrated Cancer Therapy 6, 146-157.

Tanaka, H., Shibata, M., Ohira, K., Ito, K. (1985) Total synthesis of ( \pm )-silybin, an antihepatotoxic flavanolignan. Chemical and Pharmaceutical Bulletin 33, 1419-1423.

Tůmová, L., Ǩimáková, J., Tůma, J., Dušek, J. (2006) Silybum marianum in vitro-flavonolignan production. Plant Soil and Environment 52(10), 454-458.

van der Fits, L., Memelink, J. (2000) ORCA3, a jasmonate responsive transcriptional regulator of plant primary and secondary metabolism. Science 289, 295-297.

Verpoorte, R., Alfermann, A.W. (2000) Metabolic Engineering of Plant Secondary Metabolism. Kluwer Academic Publishers, The Netherlands. 
Wagner, H., Baldt, S., Rickl, V. (2009) Plant Drug Analysis: A Thin Layer Chromatography Atlas. Second Edition, Springer, Germany.

Wang, K., Zhang, H., Shen, L., Du, Q., Li, J. (2010) Rapid separation and characterization of active flavonolignans of Silybum marianum by ultra-performance liquid chromatography coupled with electrospray tandem mass spectrometry. Journal of Pharmaceutical and Biomedical Analysis 53, 1053-1057.

Wilasrusmee, C., Kittur, S., Shah, G., Siddiqui, J., Bruch, D., Wilasrusmee, S., Kittur, D.S. (2002) Immunostimulatory effect of Silybum marianum (milk thistle) extract. Medical Science Monitor 8, BR439-434.

Zhao, B., Wolf, D.M., Agrawal, R. (1999) Inhibition of human carcinoma cell growth and DNA synthesis by silybinin, an active constituent of milk thistle: comparison with silymarin. Cancer Letters 147, 77-84.

Zhao, J., Davis, L.C.T., Verpoorte R. (2005) Elicitor signal transduction leading to production of plant secondary metabolites. Journal of Biotechnology 23, 283-333.

Zi, X., Mukhtar, H., Agarwal R. (1997) Novel cancer chemopreventative effects of a flavonoid constituent silymarin: inhibition of mRNA expression of an endogenous tumor promoter TNF alpha. Biochemical and Biophysical Research Communications $239,334-339$. 


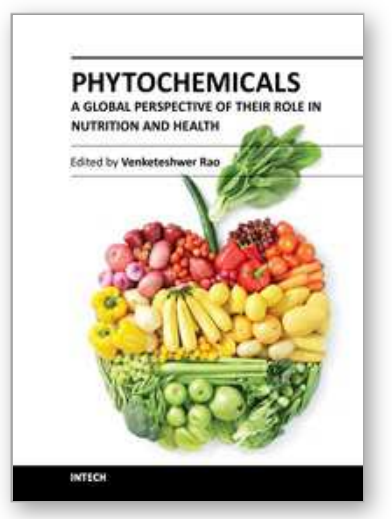

\section{Phytochemicals - A Global Perspective of Their Role in Nutrition and Health \\ Edited by Dr Venketeshwer Rao}

ISBN 978-953-51-0296-0

Hard cover, 538 pages

Publisher InTech

Published online 21, March, 2012

Published in print edition March, 2012

Phytochemicals are biologically active compounds present in plants used for food and medicine. A great deal of interest has been generated recently in the isolation, characterization and biological activity of these phytochemicals. This book is in response to the need for more current and global scope of phytochemicals. It contains chapters written by internationally recognized authors. The topics covered in the book range from their occurrence, chemical and physical characteristics, analytical procedures, biological activity, safety and industrial applications. The book has been planned to meet the needs of the researchers, health professionals, government regulatory agencies and industries. This book will serve as a standard reference book in this important and fast growing area of phytochemicals, human nutrition and health.

\section{How to reference}

In order to correctly reference this scholarly work, feel free to copy and paste the following:

Sameh AbouZid (2012). Silymarin, Natural Flavonolignans from Milk Thistle, Phytochemicals - A Global Perspective of Their Role in Nutrition and Health, Dr Venketeshwer Rao (Ed.), ISBN: 978-953-51-0296-0, InTech, Available from: http://www.intechopen.com/books/phytochemicals-a-global-perspective-of-their-role-innutrition-and-health/silymarin-natural-flavonolignans-from-milk-thistle

\section{INTECH}

open science | open minds

\section{InTech Europe}

University Campus STeP Ri

Slavka Krautzeka 83/A

51000 Rijeka, Croatia

Phone: +385 (51) 770447

Fax: +385 (51) 686166

www.intechopen.com

\section{InTech China}

Unit 405, Office Block, Hotel Equatorial Shanghai

No.65, Yan An Road (West), Shanghai, 200040, China

中国上海市延安西路65号上海国际贵都大饭店办公楼 405 单元

Phone: +86-21-62489820

Fax: +86-21-62489821 
(C) 2012 The Author(s). Licensee IntechOpen. This is an open access article distributed under the terms of the Creative Commons Attribution 3.0 License, which permits unrestricted use, distribution, and reproduction in any medium, provided the original work is properly cited. 